\title{
Geochemical Assessment of Desulphurized Tailings as Cover Material in Cold Climates
}

\author{
Asif Qureshi *(D), Bruno Bussière, Mostafa Benzaazoua (D), Fannie Lessard and Vincent Boulanger-Martel \\ Institut de Recherche en Mines et en Environnement, Université du Québec en Abitibi-Témiscamingue, \\ Rouyn-Noranda, QC J9X 5E4, Canada; Bruno.Bussiere@uqat.ca (B.B.); Mostafa.Benzaazoua@uqat.ca (M.B.); \\ fannie.lessard@snclavalin.com (F.L.); Vincent.Boulanger-Martel2@uqat.ca (V.B.-M.) \\ * Correspondence: Asif.Qureshi@uqat.ca
}

Citation: Qureshi, A.; Bussière, B.; Benzaazoua, M.; Lessard, F.; Boulanger-Martel, V. Geochemical Assessment of Desulphurized Tailings as Cover Material in Cold Climates. Minerals 2021, 11, 280. https://doi.org/10.3390/min11030280

Academic Editor: Juan Antelo

Received: 27 January 2021

Accepted: 2 March 2021

Published: 9 March 2021

Publisher's Note: MDPI stays neutral with regard to jurisdictional claims in published maps and institutional affiliations.

Copyright: (c) 2021 by the authors. Licensee MDPI, Basel, Switzerland. This article is an open access article distributed under the terms and conditions of the Creative Commons Attribution (CC BY) license (https:// creativecommons.org/licenses/by/ $4.0 /)$.

\begin{abstract}
It is essential to develop effective mine waste management approaches and mine site reclamation techniques to curtail the adverse effects of mining processes on the natural environment. This study focuses on the use of partially desulphurized tailings as a moisture-retaining layer in an insulation cover with capillary barrier effects (ICCBE). Tailings were obtained from a nickel ultramafic ore processing plant at a mining company located in a continuous permafrost region of northern Québec, Canada. The geochemical response of tailings at two different sulphur contents (0.4 and $0.8 \mathrm{wt} \%)$, with and without ICCBEs, was tested by applying eight freeze-thaw and wetting cycles. Desulphurization of the tailings allowed to reduce the content of sulphide minerals by about $90 \%$, from $\sim 22 \mathrm{wt} \%$ to around 1.2-2.2 wt\%. Column kinetic geochemical tests showed that $\mathrm{Ni}$ leaching was significantly reduced to concentrations ranging between $0.01-0.22 \mathrm{mg} \mathrm{L}^{-1}$ compared to $0.63-1.92 \mathrm{mg} \mathrm{L}^{-1}$ from the raw tailings (thanks to the desulphurization process). Zinc release was maintained around $0.04-1.72 \mathrm{mg} \mathrm{L}^{-1}$ compared to $0.4-3.69 \mathrm{mg} \mathrm{L}^{-1}$ from the raw tailing. Although all the columns produced leachates displaying circumneutral to slightly alkaline $\mathrm{pH}$, the columns with ICCBE are expected to prevent acid mine drainage generation longer than the other columns due to reduced sulphide content and a constantly high degree of saturation maintained by capillary barrier effects.
\end{abstract}

Keywords: insulation cover with capillary barrier effect (ICCBE); desulphurized tailings; acid mine drainage; freeze and thaw cycles; environmental performance; cold climates; permafrost regions; metal mining

\section{Introduction}

Metals and minerals extracted from the earth through mining significantly contribute to the economy of many countries worldwide. However, mining operations, alongside positive economic impact, produce substantial volumes of solid wastes that can pose environmental risks to the natural environment. The main waste products produced from mining operations include waste rocks (WRs) and tailings (produced during ore processing) [1].

These WRs and tailings sometimes contain sulphide minerals (such as pyrite, arsenopyrite and pyrrhotite), which are unstable in atmospheric conditions (react with oxygen) and, upon receiving water, produce acidic leachates (known as Acid Mine Drainage or AMD). AMD is characterized by low $\mathrm{pH}$ and can contain elevated elemental concentrations of metals and metalloids [1-4]. Different technologies have been developed to avoid contamination from AMD generating wastes, and the selection of the most appropriate technology for a given site is a function of many factors such as the climatic conditions, material properties and availability, topography, mine waste reactivity, and in situ thermal and hydrogeological conditions $[2,3,5,6]$.

For mine sites located in northern areas close to the Arctic, factors such as climate change, the presence of permafrost, remoteness, the availability of materials, and harsh 
climatic conditions can make the design and construction of reclamation scenarios more difficult and expensive than for mines in temperate climates [7]. Few alternatives are available to reclaim mine sites located in Arctic conditions. While some methods are only a transfer from those used in the South, one technique called insulation covers was explicitly proposed for Arctic conditions that aim at maintaining the mine tailings frozen and below a target temperature to prevent sulphide mineral reactivity [6,8-12]. More recently, a new alternative was proposed to improve the performance of Arctic reclamation scenarios against climate change: the insulation cover system with capillary barrier effects (ICCBEs) $[8,10,13,14]$. ICCBEs could reduce the time for which the tailings are above freezing temperature and control oxygen fluxes when the tailings are unfrozen. The moisture-retaining layer (MRL) is the main component of such a cover system that maintains a high degree of saturation $\left(\mathrm{S}_{\mathrm{r}}\right)$ and significantly restricts oxygen flux from reaching the acid-generating tailings. The MRL is usually constructed from fine-grained silty materials $[15,16]$.

It can be challenging in Arctic regions to find the fine-grained materials required to build the MRL [10]. The possibility of producing desulphurized tailings through a nonselective froth flotation process in processing plants on-site $[4,17,18]$ makes desulphurized tailings an attractive and potential alternative to natural fine-grained cover materials [17,19]. Aubertin et al. [20] and Bussière et al. [16,17], for instance, have reported CCBEs with an MRL made of low sulphide tailings as an effective technique to restrict AMD generation.

The setup tested in the present study consists of columns representing an ICCBE. The columns were subjected to the artificial field inspired climatic conditions (temperature and precipitation) to test the hydrogeological behaviour of ICCBEs constructed from desulphurized tailings and non-acid generating waste rocks and assess their potential for preventing acid-generating tailings from receiving oxygen flux, thus AMD generation. The details on the desulphurization of the tailings are reported in Benzaazoua et al. [18].

The columns were subjected to freeze-thaw cycles whereupon the columns were frozen at the temperature conditions inspired by the observed soil temperature conditions at the Raglan Mine site [10]. The hydrogeological results from the columns showed a constant high $\mathrm{S}_{\mathrm{r}}(\geq 85 \%)$ and oxygen fluxes through ICCBEs lower than $5.5 \times 10^{-3} \mathrm{~mol} / \mathrm{m}^{2} /$ day [10]. Such high $S_{r}$ and oxygen fluxes have been reported effective for CCBEs to limit AMD generation [21-25]. Notwithstanding the good hydrogeological performance of the tested ICCBEs, questions remain concerning the potential of the desulphurized tailings used as MRL to generate contaminants.

Indeed, before using any material in an engineered cover, it is crucial to demonstrate that the material used would not generate environmental problems in the short and long term. This study's primary objective consists of validating the hypothesis that the desulphurization of Raglan Mine's tailings is a viable option to produce clean tailings that can be used as MRL in ICCBEs. The specific objectives aim at (i) characterizing the environmental behaviour of ICCBEs made from desulphurized tailings and non-acid generating WRs using laboratory column experiments; (ii) evaluating the impact of two sulphur contents in desulphurized tailings as MRL in ICCBEs on leachate quality and (iii) comparing the environmental behaviour of ICCBEs made from desulphurized tailings and non-acid generating WRs with only desulphurized tailings and fresh AMD generating tailings under same experimental conditions. The tailings obtained from the Raglan Mine were desulphurized and characterized for their physical, mineralogical, and chemical composition and environmental behaviour $[10,18]$. The hydrogeological behaviour of the tailings under the same experimental conditions has been reported by Lessard et al. [10]. Therefore, this article focuses explicitly on desulphurized tailings' geochemical behaviour (with and without ICCBEs) and compares it with the original (or raw) tailings using column experiments. 


\section{Materials and Methods}

\subsection{Materials}

Raw tailings and WRs were sampled from Raglan Mine, located at the extreme limit of Northern Quebec, Canada. Four mine sites typically provide the Ni-sulphide ores; ore mixes are made and processed in the mill using froth flotation. Approximately 1.3 MT of tailings are produced yearly from the processing plants at Raglan Mine. The two samples of desulphurized tailings are designated as DST1 and DST2 here, and that of raw (original) tailings as RT. More details about the location of sampling and the concentrator's overall flow-diagram can be found in Benzaazoua et al. [18].

\subsection{Methods}

Two samples of tailings were desulphurized in the lab using the froth flotation process (see Benzaazoua et al. [18] for details). Briefly, a Denver D-12 lab flotation machine with a cell volume of $2.5 \mathrm{~L}$ was used with a rotor-stator speed of $1500 \mathrm{rpm}$ and airflow of $2.25 \mathrm{~L} \mathrm{~min}^{-1}$. A programmed system with a spatula was used to remove the froths mechanically. Potassium amyl xanthate (KAX-51; purity of $95 \mathrm{wt} \%$ ) and Sodium isobutyl xanthate (SIBX) were used as Collectors, Methyl isobutyl carbinol (MIBC) was used as Frother, hydrated copper sulphate as Activator; and sodium hydroxide $(\mathrm{NaOH})$ as $\mathrm{pH}$ regulator.

The desulphurized tailings and WR particles smaller than $300 \mu \mathrm{m}$ were characterized for grain-size distribution using a Malvern Instruments Mastersizer S laser particle size analyser. WR particles larger than $300 \mu \mathrm{m}$ were characterized by mechanical sieving as described by ASTM D422 [26], details in Coulombe [27].

Mineralogical characterization was performed using optical microscopy first and then by both scanning electron microscopy (SEM; Hitachi S-3500 N, Japan) coupled with Energy Dispersive Spectrometry (EDS; Silicon Drift Detector X-Max $20 \mathrm{~mm}^{2}$ from Oxford, UK) microanalysis, and X-ray diffraction (XRD; Bruker AXS Advance D8, Billerica, MA, USA; XRD precision $\pm 1 \%$; [28]).

The inductively coupled plasma atomic emission spectroscopy (ICP-AES; Perkin Elmer 3000 DV, Überlingen, Germany) for trace metal in particular and fusion, whole-rock analyses by borate fused disc, were used to determine the major and minor elemental composition of the desulphurized tailings. Analyses of total inorganic carbon (C) and sulphur (S) concentrations were also carried out using an induction furnace equipped with a dedicated infrared (IR) analyser (Eltra CS 2000, Haan, Germany) with a \pm 0.05 to 0.1 wt $\%$ precision [29].

After the experiment, DST1, DST2, and RT columns (Table 1) were partially dismantled by cutting a disc of $0.5 \mathrm{~m}$ thickness from the top (most weathered) and the bottom (considered the least weathered) of the column for complementary chemical and mineralogical analyses following the methods mentioned above.

Table 1. Designation and details of columns.

\begin{tabular}{cl}
\hline Column Designation & \multicolumn{1}{c}{ Details } \\
\hline \multirow{2}{*}{ ICCBE-DST1 } & Column with ICCBE: $\sim 0.50 \mathrm{~m}$ support layer from non-acid generating WRs, 0.70 m MRL layer from \\
& DST 1, 0.40 m protective layer from non-acid generating WRs. Total height 2.10 m and 0.14 m diameter. \\
ICCBE-DST2 & Column with ICCBE: $\sim 0.50 \mathrm{~m}$ support layer from non-acid generating WRs, $0.70 \mathrm{~m}$ MRL layer from DST 2, \\
DST1 & $0.40 \mathrm{~m}$ protective layer from non-acid generating WRs. The total height of $2.10 \mathrm{~m}$ and $0.14 \mathrm{~m}$ diameter. \\
DST2 & Column without ICCBE: $0.70 \mathrm{~m}$ single layer of DST 1 . The total height of $0.80 \mathrm{~m}$ and $0.14 \mathrm{~m}$ diameter. \\
RT & Column without ICCBE: $0.70 \mathrm{~m}$ single layer of DST 2 . The total height of $0.80 \mathrm{~m}$ and $0.14 \mathrm{~m}$ diameter. \\
\hline
\end{tabular}

Additionally, due to complexity in the interpretation of the higher sulphate leaching, the materials from the top and the bottom of the columns were also analysed using X-ray absorption near edge structure (XANES) spectroscopy at the Soft X-ray Microcharacterization Beamline (SXRMB; 06B1-1) facility at Canadian Light Source Inc. (CLSI), Saskatchewan (Canada) for fingerprinting and analyses of the crystal chemistry of sulphide and all other 
sulphur minerals, following the method proposed by Moncur et al. [30]. Briefly, a sample of $\sim 5 \mathrm{~g}$ from the top and each column's base was freeze-dried under vacuum at $-45^{\circ} \mathrm{C}$ and pulverized with an agate mill. A portion of the powdered sample was then placed on a copper plate using copper tape before transferring the sample into the vacuum chamber of the SXRMB facility. A Si(111) crystal monochromator was used to collect the spectra in triplicate for each sample ( 6 samples $\times 3$ replicates) under the total electron yield mode. The spectra were also collected for the reference materials in duplicates such as gypsum, cobalt sulphate, ferrous sulphate, jarosite, and nickel sulphate. Reference spectra for the thiosulphate, native sulphur, pyrite, pyrrhotite, and pentlandite were provided by the researchers at UWaterloo, Canada databank. The ATHENA (part of the IFEFFIT software suite [31]) was used for data processing, analysis, and interpretation. According to the first derivative maxima, all spectra were calibrated to the theoretical S8 K-edge energy (E0; $2472.0 \mathrm{eV}$ ). Linear combination fitting of normalized spectra was constrained by fixing $\mathrm{E}_{0}$ values to calibrated energies and limiting total reference spectra to four.

The desulphurized tailings' AMD generation potential was determined from their neutralization potential (NP) and acid generation potential (AP). The NP of the samples was determined using the modified method of Sobek et al. [32], as proposed by Lawrence and Scheske [33], and the AP was calculated by multiplying sulphur content with $31.25 \mathrm{~kg}$ $\mathrm{CaCO}_{3} /$ ton (sulphur as sulphide content after sulphates subtraction). The AMD generating potential was then determined according to the widely used net neutralization potential $(\mathrm{NNP}=\mathrm{NP}-\mathrm{AP})$ and neutralization potential ratio $(\mathrm{NPR}=\mathrm{NP} / \mathrm{AP})$ criteria.

\subsection{Environmental Performance of ICCBEs}

For evaluating the overall environmental performance of the ICCBEs constructed from the desulphurized tailings (DST) and the WRs, the ICCBEs were implemented in columns. The columns were subjected to freeze-thaw cycles and leaching experiments by applying cyclic temperature changes to assess freeze-thaw cycles' effects. The effects of such experimental conditions on the hydrogeological and thermal behaviour of the ICCBEs are reported in Lessard et al. [10].

\subsubsection{Experimental Design}

The ICCBE columns (Figure 1) were constructed from high-density polyethylene (HDPE) with an internal diameter of $0.14 \mathrm{~m}$, a wall thickness of $\sim 0.022 \mathrm{~m}$, and a height of $2.20 \mathrm{~m}$. The columns were filled with a coarse-grained support layer (or capillary break layer; CBL) at the bottom $(1.0 \mathrm{~m})$ utilizing crushed non-acid generating WRs followed by a $0.70 \mathrm{~m}$ thick desulphurized tailings as MRL and a protective layer (PL) of $0.40 \mathrm{~m}$ thickness made from the same crushed non-acid generating WRs, with a $0.10 \mathrm{~m}$ headroom for flushing. One column for each of the two desulphurized tailings was constructed.

The crushed rock layers (CBL and PL) were compacted to a porosity of approximately 0.25 . Whereas a porosity of $0.36-0.40$ was achieved for the desulphurized tailings. The initial unfrozen volumetric water content $\left(\theta_{\mathrm{u}}\right)$ was 0.36 in desulphurized tailings MRL ( $\mathrm{S}_{\mathrm{r}}$ between $90-100 \%$ ). Two more columns without ICCBE, each at height $0.80 \mathrm{~m}$ with $0.14 \mathrm{~m}$ diameter containing only DST 1 and DST 2, were also tested to understand the desulphurized tailings' geochemical behaviour better. A control column $(\mathrm{H}: 0.80 \mathrm{~m}, \varnothing$ : $0.14 \mathrm{~m}$ ) containing highly sulphidic raw tailings (RT) was also subjected to the same experimental conditions. The details of the columns and their designation are given in Table 1.

Due to the critical height of the ICCBE columns, two detachable parts for the facilitation of the installation and instrumentation were joined with Victaulic ${ }^{\circledR}$ joints. The junction between two parts of the columns was located above the capillary break at the MRL's bottom to avoid any disturbance to this critical (MRL) layer (Figure 1). The columns' base was concealed with customized polyethylene support for compatibility to hold a porous ceramic plate. The outflow of the leachate and gas purge valves were installed at the base 
of the columns. A $0.254 \mathrm{~m}$ Styrofoam insulation was used around the columns to minimize lateral heat transfers along the column wall.
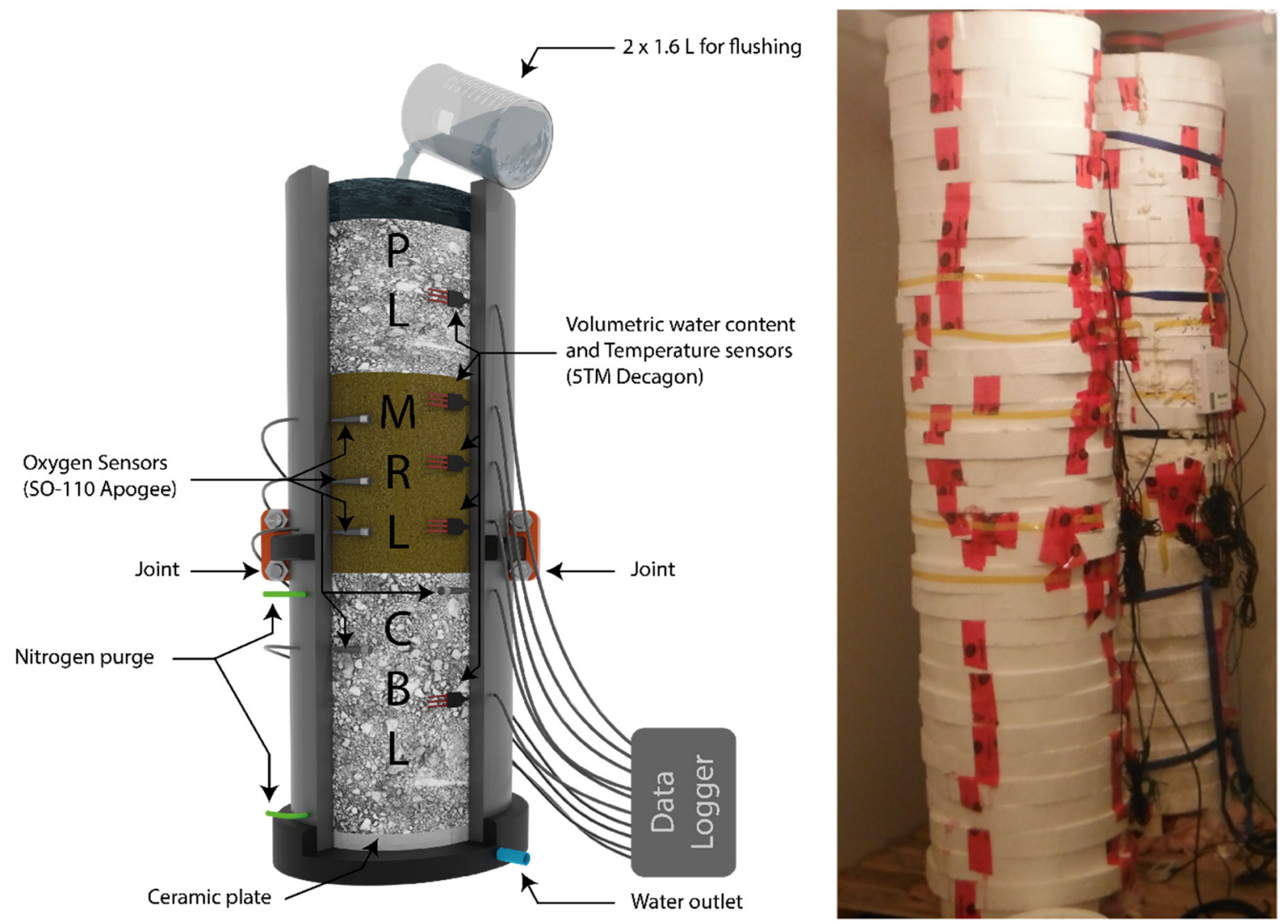

Figure 1. ICCBE based column configuration and instrumentation (Left), and Styrofoam insulated columns placed in the temperature-controlled chamber (Right).

Columns were instrumented with different sensors to measure the temperature, volumetric water content, oxygen concentration, and suction. The results from sensors will not be presented and discussed here because this article focuses on the columns' geochemical behaviour (see Lessard et al. [10] for details).

\subsubsection{Experimental Approach}

The column experiments were intended to test: (i) ICCBEs for their potential to control oxygen migration (which ultimately controls AMD generation), (ii) evolution of temperature throughout the columns upon exposure to freeze-thaw cycles, and distribution of $\theta_{\mathrm{w}}$ within the ICCBEs, and (iii) effect of using desulphurized tailings with two different sulphur contents as MRL on elemental leaching and water quality of ICCBEs. Since (i) and (ii) are discussed in Lessard et al. [10], this article focuses on (iii).

Before starting the experiments, the columns were exposed to a $5{ }^{\circ} \mathrm{C}$ controlled environment for 27 days following a typical testing sequence (Figure 2), beginning with a 7-day rinse with two volumes of $1.6 \mathrm{~L}$ of deionized water each at $24 \mathrm{~h}$ intervals. At the end of the rinse period, the collected leachates were analysed for $\mathrm{pH}, \mathrm{Eh}, \mathrm{EC}$, acidity, and alkalinity before chemical characterization using ICP, following the methods and protocols previously mentioned in Section 2.2 above.

After the flush, the columns were exposed to a $5{ }^{\circ} \mathrm{C}$ temperature for another 10 days before subjecting them to the F-T cycle of 20 days (10-day freezing and 10-day thawing). The F-T cycles were performed by exposing the columns to temperature conditions inspired by those at the Raglan Mine site [10]. A proportional-integral-derivative (PID) controlled industrial grade freezer was used to maintain the temperatures of $-13^{\circ} \mathrm{C}$ (for freezing) 
and $5{ }^{\circ} \mathrm{C}$ (for thawing), as applied by Boulanger-Martel et al. [8,34] before. A total of eight such leachings and $\mathrm{F}-\mathrm{T}$ cycles were performed over a period of a year.

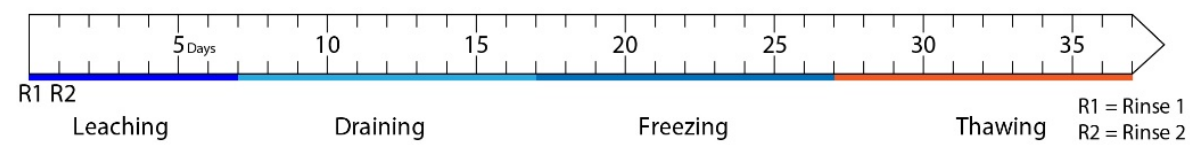

Figure 2. Typical testing sequence in a cycle.

\section{Results and Discussion}

\subsection{Physical, Mineralogical, and Chemical Characteristics of the Materials}

The particle size distribution of RT, DST, and crushed WRs, along with the coefficient of curvature $\left(\mathrm{C}_{\mathrm{C}}\right)$ and coefficient of uniformity $\left(\mathrm{C}_{\mathrm{U}}\right)$ are presented in Table 2. According to the USCS soil classification [35], the RT and DST were classified as low plasticity silts (ML, similar to other hard rock mine tailings; [15]), and the WRs were classified as well-graded gravel (GW) after the crushing.

Table 2. Grain size distribution of desulphurized tailings and waste rocks.

\begin{tabular}{|c|c|c|c|c|c|c|c|}
\hline Material & $\mathrm{D}_{10}(\mathrm{~mm})$ & $\mathrm{D}_{30}(\mathrm{~mm})$ & $\mathrm{D}_{50}(\mathrm{~mm})$ & $\mathrm{D}_{60}(\mathrm{~mm})$ & $\mathrm{C}_{\mathrm{C}}^{\mathrm{a}}$ & $\mathrm{C}_{U}^{\mathrm{b}}$ & Classification $^{\mathrm{c}}$ \\
\hline RT & 0.00256 & 0.0084 & 0.0238 & 0.0398 & 0.69 & 15.6 & $M L^{d}$ \\
\hline DST1 & 0.0028 & 0.0095 & 0.0268 & 0.0430 & 0.75 & 15.3 & $\mathrm{ML}^{\mathrm{d}}$ \\
\hline DST2 & 0.0026 & 0.0086 & 0.0243 & 0.0395 & 0.71 & 15.0 & $M L^{d}$ \\
\hline WRs * & 0.104 & 3.4 & 8.0 & 10.0 & 11.14 & 96.2 & $\mathrm{GW}^{\mathrm{e}}$ \\
\hline
\end{tabular}

${ }^{*}$ after Coulombe [27]; ${ }^{a} C_{C}=$ Coefficient of curvature; ${ }^{b} C_{U}=$ Coefficient of uniformity; ${ }^{c}$ USCS soil classification after McCarthy [35];

${ }^{\mathrm{d}} \mathrm{ML}=$ low plasticity silts; ${ }^{\mathrm{e}} \mathrm{GW}=$ well-graded gravel.

The difference between particle sizes of DST (and RT) and WRs resulted in a significant difference between hydraulic conductivities of tailings and WRs $\left(\mathrm{k}_{\mathrm{sat}}=1.1 \times 10^{-7}\right.$ and $3.4 \times 10^{-3} \mathrm{~m} / \mathrm{s}$, respectively; [10]). A difference greater than three-order in $\mathrm{k}_{\mathrm{sat}}$ values of the two materials is recommended to create significant capillary barrier effects, which allows maintaining a high $\mathrm{S}_{\mathrm{r}}(>85 \%)$ and restricting the oxygen migration $\left(<5.5 \times 10^{-3} \mathrm{~mol} / \mathrm{m}^{2} /\right.$ day $)$ through the materials $[10,36]$.

A significant difference was also observed in the mineralogical composition of RT, DST, and WRs (Table 3). The primary sulphide minerals included pyrrhotite and pentlandite with traces of pyrite and chalcopyrite and non-acid generating gangue minerals [18]. After the desulphurization, the sulphide minerals were reduced from $21.8 \mathrm{wt} \%$ to 1.2 and $2.2 \mathrm{wt} \%$ in DST1 and DST2, respectively, along with enriched non-sulfidic non-acid generating gangue minerals (actinolite, clinochlore, and lizardite). The WRs were composed of nonsulfidic and non-acid generating gangue minerals (actinolite, albite, anorthite, clinochlore, and epidote).

The availability of reactive mineral surfaces was observed to be a function of the particle size distribution of the DST. Smaller particle sizes contained higher available reactive minerals (pyrrhotite and pentlandite) in free form, whereas sulphide minerals were predominantly mixed with gangue (non-sulfidic) minerals in larger particles, as indicated by QEMScan [18]. Pyrrhotite and pentlandite were often occurring as intergrowth particles or inclusions within lizardite.

The DSTs' chemical composition (Table 4) revealed that the tailings contained only $0.4-0.8 \mathrm{wt} \%$ total sulphur $\left(\mathrm{S}_{\text {tot }}\right)$, indicating minimal sulphide content. However, enriched $\mathrm{Al}, \mathrm{Fe}, \mathrm{Ca}, \mathrm{Mg}$, and Na were mainly due to high non-sulfidic gangue mineral content within the DST. All the measured $S_{\text {tot }}$ was primarily associated with pyrrhotite and pentlandite by QEMScan previously performed on the DST by Benzaazoua et al. [18].

The tailings' physical, mineralogical, and chemical composition indicates that the DSTs would not be highly reactive and would be suitable material for the MRL because of their geochemical and hydrogeological properties [10]. 
Table 3. Mineralogical composition of the tailings and WRs.

\begin{tabular}{|c|c|c|c|c|c|}
\hline $\begin{array}{c}\text { Mineral } \\
\text { (\% by Weight) }\end{array}$ & Chemical Formula & $\mathrm{RT}^{\mathrm{a}}$ & DST1 & DST2 & $W_{R s}{ }^{b}$ \\
\hline Actinolite & $\mathrm{Ca}_{2}(\mathrm{Mg}, \mathrm{Fe})_{5} \mathrm{Si}_{8} \mathrm{O}_{22}(\mathrm{OH})_{2}$ & 14.0 & 29.75 & 30 & 33.6 \\
\hline Albite & $\mathrm{NaAlSi}_{3} \mathrm{O}_{8}$ & - & 2.76 & 3.86 & 14.4 \\
\hline Anorthite & $\mathrm{CaAl}_{2} \mathrm{Si}_{2} \mathrm{O}_{8}$ & - & - & - & 11.2 \\
\hline Calcite & $\mathrm{CaCO}_{3}$ & - & 2.17 & 2.17 & - \\
\hline Chalcopyrite & $\mathrm{CuFeS}_{2}$ & 0.46 & 0.25 & 0.25 & - \\
\hline Chamosite & $(\mathrm{Fe}, \mathrm{Mg})_{5} \mathrm{Al}\left(\mathrm{Si}_{3} \mathrm{Al}\right) \mathrm{O}_{10}(\mathrm{OH}, \mathrm{O})$ & 8.0 & - & - & - \\
\hline Clinochlore & $(\mathrm{Mg}, \mathrm{Fe})_{5} \mathrm{Al}\left(\mathrm{Si}_{3}, \mathrm{Al}\right) \mathrm{O}_{10}(\mathrm{OH})_{8}$ & - & 26.48 & 26.12 & 14.7 \\
\hline Dolomite & $\mathrm{CaMg}\left(\mathrm{CO}_{3}\right)_{2}$ & 1.90 & - & - & - \\
\hline Epidote & $\mathrm{Ca}_{2}(\mathrm{Fe}, \mathrm{Al}) \mathrm{Al}_{2}\left(\mathrm{SiO}_{4}\right)\left(\mathrm{Si}_{2} \mathrm{O}_{7}\right) \mathrm{O}(\mathrm{OH})$ & - & - & - & 17.5 \\
\hline Hornblende & $(\mathrm{Ca}, \mathrm{Na}, \mathrm{K})_{2}\left(\mathrm{Mg}, \mathrm{Fe}^{2+}, \mathrm{Fe}^{3+}, \mathrm{Al}_{5}\left[\mathrm{Si}_{6}(\mathrm{Al}, \mathrm{Si})_{2} \mathrm{O}_{22}\right](\mathrm{OH}, \mathrm{F})_{2}\right.$ & 7.17 & - & - & - \\
\hline Lizardite & $\mathrm{Mg}_{3} \mathrm{Si}_{2} \mathrm{O}_{5}(\mathrm{OH})_{4}$ & 32.0 & 31.81 & 30.9 & - \\
\hline Magnetite & $\mathrm{Fe}_{3} \mathrm{O}_{4}$ & 5.0 & 2.56 & 2 & - \\
\hline Orthoclase & $\mathrm{KAlSi}_{3} \mathrm{O}_{8}$ & - & 1.37 & 1.3 & - \\
\hline Pentlandite & $(\mathrm{Fe}, \mathrm{Ni})_{9} \mathrm{~S}_{8}$ & 1.2 & 0.29 & 0.4 & - \\
\hline Pyrite & $\mathrm{FeS}_{2}$ & 0.14 & - & - & - \\
\hline Pyrrhotite & $\mathrm{Fe}_{1-\mathrm{x}} \mathrm{S}(\mathrm{x}=0-0.17)$ & 20.0 & 0.64 & 1.55 & - \\
\hline Quartz & $\mathrm{SiO}_{2}$ & 1.0 & 1.60 & 1.12 & 8.3 \\
\hline Rutile & $\mathrm{TiO}_{2}$ & - & 0.30 & 0.3 & 0.5 \\
\hline Talc & $\mathrm{Mg}_{3} \mathrm{Si}_{4} \mathrm{O}_{10}(\mathrm{OH})_{2}$ & 7.0 & - & - & - \\
\hline Titanite & $\mathrm{CaTiSiO}_{5}$ & 2.13 & - & - & - \\
\hline
\end{tabular}

a after Benzaazoua et al. [18]; ${ }^{b}$ after Coulombe [27].

Before desulphurization, the tailings contained 3.9-8.1 $\mathrm{wt} \% \mathrm{~S}$ distributed in pyrrhotite with some residual pentlandite and chalcopyrite traces, and a net-neutralization potential (NNP) varying between -95 and $-224 \mathrm{~kg} \mathrm{CaCO}_{3} /$ ton [18], indicating a strongly acid-generating material. The desulphurization process reduced the sulphur content to $0.4-0.8 \mathrm{wt} \%$ and the NNP to $2.8-13.5 \mathrm{~kg} \mathrm{CaCO}_{3} /$ ton [18]. Hence, the AMD generating potential of DST (Table 4) remained in the uncertain region $\left(-20<\mathrm{NNP}<20 \mathrm{~kg} \mathrm{CaCO}_{3} /\right.$ ton). It is worth mentioning that Benzaazoua et al. [18] recalculated the AP of the tailings by taking into account the liberation of pyrrhotite and reported an NNP $>20$, indicating that the tailings were non-acid generating.

Table 4. AMD potential and chemical composition of the tailings and WRs.

\begin{tabular}{ccccc}
\hline Property & RT $^{\mathbf{a}}$ & DST1 & DST2 & WRs $^{\mathbf{b}}$ \\
\hline $\mathrm{AP}\left(\mathrm{kg} \mathrm{CaCO}_{3}\right.$ ton $\left.^{-1}\right)$ & 255.63 & 14.44 & 25.16 & N.D. \\
$\mathrm{NP}\left(\mathrm{kg} \mathrm{CaCO}_{3}\right.$ ton $\left.^{-1}\right)$ & 27.49 & 28 & 28 & 26.66 \\
$\mathrm{NNP}\left(\mathrm{kg} \mathrm{CaCO}_{3}\right.$ ton $\left.^{-1}\right)$ & -223.96 & 13.56 & 2.84 & N.D. \\
$\mathrm{NPR}(-)$ & 0.11 & 1.94 & 1.12 & N.D. \\
$\mathrm{Al}$ & $\mathrm{Chemical} \mathrm{composition}\left(\mathrm{mg} \mathrm{kg}^{-1}\right)$ & & 65,300 \\
$\mathrm{As}$ & 15,580 & 33,010 & 30,160 & $<10$ \\
$\mathrm{Ca}$ & $<5.0$ & 5.83 & $<5.0$ & 64,900 \\
$\mathrm{Cr}$ & 10,120 & 33,790 & 30,060 & 180 \\
$\mathrm{Cu}$ & 1817 & 1840 & 1789 & 170 \\
$\mathrm{Fe}$ & 1353 & 861.5 & 1024 & 72,900 \\
$\mathrm{~K}$ & 124,700 & 83,260 & 77,570 & N.D. \\
$\mathrm{Mg}$ & 550 & 1950 & 141,800 & 41,200 \\
$\mathrm{Mn}$ & 168,700 & 151,900 & 1219 & 1080 \\
$\mathrm{Na}$ & 771 & 1199 & 4030 & 10,700 \\
$\mathrm{Ni}$ & 1730 & 3780 & 1398 & 170 \\
$\mathrm{~S}$ & 2372 & 1042 & 8041 & N.D. \\
$\mathrm{Ti}$ & 39,750 & 4039 & 1940 & N.D. \\
\hline $\mathrm{Zn}$ & 917 & 2118 & 69 & 70 \\
\hline
\end{tabular}

${ }^{\mathrm{a}}$ after Benzaazoua et al. [18]; ${ }^{\mathrm{b}}$ after Coulombe [27]; N.D. = not detected. -: This is to represent that this parameter doesn't have any unit. 


\subsection{Quality of Leachates}

The leachates from the DST columns with and without ICCBEs and the RT column always maintained a circumneutral to slightly alkaline $\mathrm{pH}$ (Figure 3). The Eh $(0.2-0.55 \mathrm{~V})$ along with such $\mathrm{pH}$ conditions also suggest that the reactivity of sulphide minerals shall be negligible and favourable for the precipitation of secondary minerals [37], thus resulting in low concentrations of elements of concern (such as $\mathrm{Al}, \mathrm{Cu}, \mathrm{Fe}, \mathrm{Ni}, \mathrm{Pb}$, and $\mathrm{Zn}$; Table 5 and Figure 3). The concentrations of these elements of concern were always lower than the acceptable concentrations outlined in the Québec Environmental Discharge Standard Limits for effluents from Mining Industries (Directive 019, D019). The permissible average limit for both $\mathrm{Ni}$ and $\mathrm{Zn}$ in D019 is $0.5 \mathrm{mg} \mathrm{L}^{-1}$. Only Zn surpassed the outlined limits after the fifth cycle from ICCBE-DST2 (Figure 3). Similar spikes were also observed in the Fe concentration (but lower than the provincial regulatory limits), indicating that the column underwent some increase in sulphide reactivity at these instances.
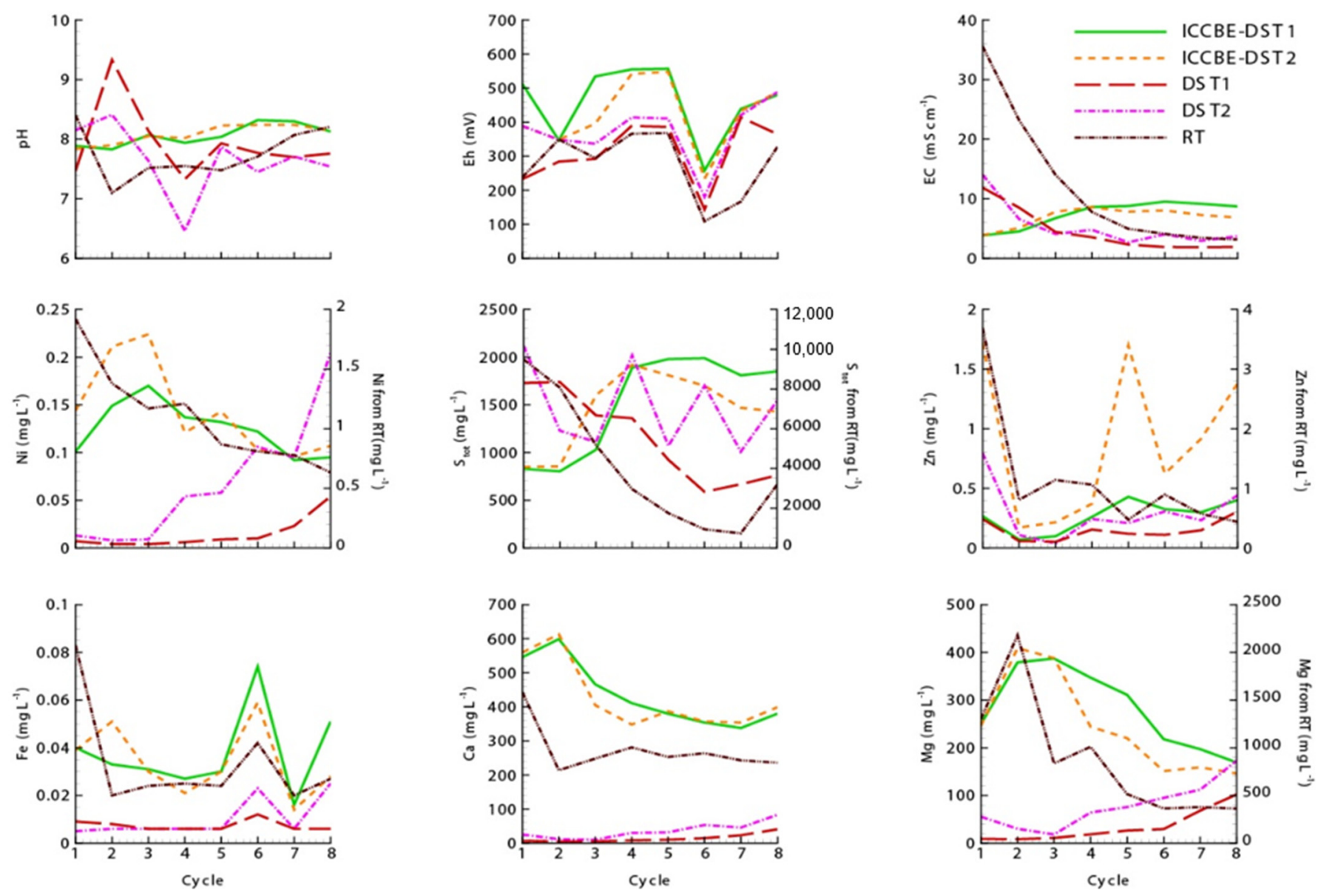

Figure 3. Physicochemical characteristics of the leachates from the columns with and without ICCBE and RT (Ni, $\mathrm{S}_{\text {tot }}, \mathrm{Zn}$ and $\mathrm{Mg}$ on the secondary $y$-axis).

A clear and concerning difference was observed for $\mathrm{Ni}$ and $\mathrm{Zn}$ concentrations from RT than DST (regardless of ICCBE). Nickel always showed a descending pattern and concentrations higher than the D019 limits. Zinc concentrations also showed similar patterns and remained above the D019 permissible limits. Pronounced leaching of $\mathrm{Ni}$ and $\mathrm{Zn}$, similar Fe leaching patterns, and dip in Eh indicate higher sulphide reactivity in the RT column.

The elements not presented in Table 5 and Figure 3 (such as As, Ba, Be, Bi, Cd, Co, Cr, $\mathrm{Li}, \mathrm{Mn}, \mathrm{Mo}, \mathrm{Pb}, \mathrm{Sb}, \mathrm{Te}$, and $\mathrm{Ti}$ ) were all below their respective detection limits. The evident difference in EC of the leachates from DST and RT also suggests higher reactivity in the RT 
column. However, after the fourth cycle, the difference diminished, and the EC from DST1, DST2, and RT became almost equal. This also shows that the ionic activity slows down in $\mathrm{RT}$, probably due to secondary mineralization, which resulted in a slight rise in $\mathrm{pH}$ with time and reduced mobility of elements.

However, the addition of non-acid generating WRs in ICCBE columns (ICCBE-DST1 and ICCBE-DST2) indicates that the WRs provide additional acid buffering minerals, resulting in more stable $\mathrm{pH}$ and $\mathrm{EC}$ conditions throughout the experimental duration (Figure 3).

Table 5. Minimum and maximum concentrations of elements in the leachates from columns.

\begin{tabular}{|c|c|c|c|c|c|c|c|c|c|c|}
\hline \multirow{2}{*}{ Property } & \multicolumn{2}{|c|}{ ICCBE-DST1 } & \multicolumn{2}{|c|}{ ICCBE-DST2 } & \multicolumn{2}{|c|}{ DST1 } & \multicolumn{2}{|c|}{ DST2 } & \multicolumn{2}{|c|}{ RT } \\
\hline & Min & Max & Min & $\operatorname{Max}$ & Min & $\operatorname{Max}$ & Min & $\operatorname{Max}$ & Min & $\operatorname{Max}$ \\
\hline $\mathrm{pH}(-)$ & 7.83 & 8.32 & 7.84 & 8.24 & 7.33 & 9.33 & 6.46 & 8.41 & 7.1 & 8.4 \\
\hline Eh $(\mathrm{mV})$ & 258 & 557 & 234 & 548 & 144 & 414 & 181 & 488 & 109 & 368 \\
\hline $\mathrm{EC}\left(\mathrm{mS} \mathrm{cm}^{-1}\right)$ & 3.86 & 9.53 & 3.9 & 8.59 & 1.89 & 11.86 & 2.71 & 14.03 & 3.18 & 35.6 \\
\hline \multicolumn{11}{|c|}{ Chemical composition $\left(\mathrm{mg} \mathrm{L}^{-1}\right)$} \\
\hline $\mathrm{Al}$ & 0.01 & 0.04 & 0.01 & 0.06 & 0.01 & 0.09 & 0.01 & 0.06 & 0.01 & 0.026 \\
\hline $\mathrm{Ca}$ & 338 & 599 & 348 & 613 & 4.88 & 40 & 9.95 & 83 & 214 & 443 \\
\hline $\mathrm{Cu}$ & 0.00 & 0.03 & 0.02 & 0.24 & 0.25 & 3.23 & 0.19 & 2.90 & 0.97 & 4.85 \\
\hline $\mathrm{Fe}$ & 0.02 & 0.07 & 0.01 & 0.06 & 0.01 & 0.01 & 0.01 & 0.03 & 0.02 & 0.08 \\
\hline $\mathrm{K}$ & 4.54 & 8.80 & 4.11 & 10.40 & 57.50 & 188 & 66 & 232 & 24.8 & 464 \\
\hline $\mathrm{Mg}$ & 169 & 387 & 146 & 409 & 8.31 & 102 & 18.20 & 173 & 361 & 2180 \\
\hline $\mathrm{Na}$ & 52 & 1750 & 46 & 1660 & 180 & 2380 & 341 & 2850 & 25.4 & 5250 \\
\hline $\mathrm{Ni}$ & 0.09 & 0.17 & 0.10 & 0.22 & 0.00 & 0.05 & 0.01 & 0.20 & 0.63 & 1.92 \\
\hline$S_{\text {tot }}$ & 803 & 1990 & 848 & 1920 & 588 & 1740 & 1010 & 2120 & 736 & 9490 \\
\hline $\mathrm{Si}$ & 52.30 & 110 & 56.30 & 104 & 7.82 & 47.40 & 6.77 & 45 & 10.20 & 47 \\
\hline $\mathrm{Zn}$ & 0.07 & 0.43 & 0.17 & 1.72 & 0.05 & 0.31 & 0.04 & 0.80 & 0.44 & 3.69 \\
\hline
\end{tabular}

$-:$ This is to represent that this parameter doesn't have any unit.

However, due to the mineral composition of WRs, the leachates from ICCBE columns were also more enriched with $\mathrm{Ca}, \mathrm{Mg}$, Si and Fe. The steadily decreasing Ni from ICCBE columns compared to increasing from the columns with only DSTs during the experiment also favour the construction of ICCBEs utilizing the WRs and DSTs.

\subsubsection{High Sulphate Leachates}

Sulphate, along with heavy metals and metalloids, is usually considered indicative of sulphide reactivity in the mine waste materials [1]. However, the sulphate concentrations in all the columns (regardless of desulphurization and ICCBE) had been maintained at elevated levels while the metals were significantly lower in the tested materials (Figure 3). Although there was a significant difference between the sulphate concentrations produced by the DST and RT (maximum concentration of $2.1 \mathrm{~g} \mathrm{~L}^{-1}$ vs. $9.4 \mathrm{~g} \mathrm{~L}^{-1}$, respectively), the sulphate concentrations from DST were expected to maintain around 100-1000 $\mathrm{mg} \mathrm{L}^{-1}$, similar to what was observed for example by Benzaazoua et al. [18] and Larochelle et al. [38] from similar tailings. Lessard et al. [10] also reported that the oxygen flux through the DST within ICCBE configuration (ICCBE-DST1 and ICCBE-DST2) was close to $5.5 \times 10^{-3} \mathrm{~mol} \mathrm{~m}^{-2} \mathrm{day}^{-1}$, which indicates a sound performing cover system to control oxygen migration [22-24] and, consequently, inhibition of AMD generation. Therefore, the XANES spectra were used to fingerprint the sulphide and other sulphur species within the weathered tailings.

The XANES treated spectra for samples from the top and the base of the DST1, DST2, and RT columns, along with reference minerals' spectra, are presented in Figure 4 . The XANES spectra clearly show that the top samples were more depleted and oxidized (with taller and broader peaks in the oxidation zone) than the bottom samples. Therefore, the bottom samples were assumed to have a geochemical composition closer to the original (fresh) tailings. 


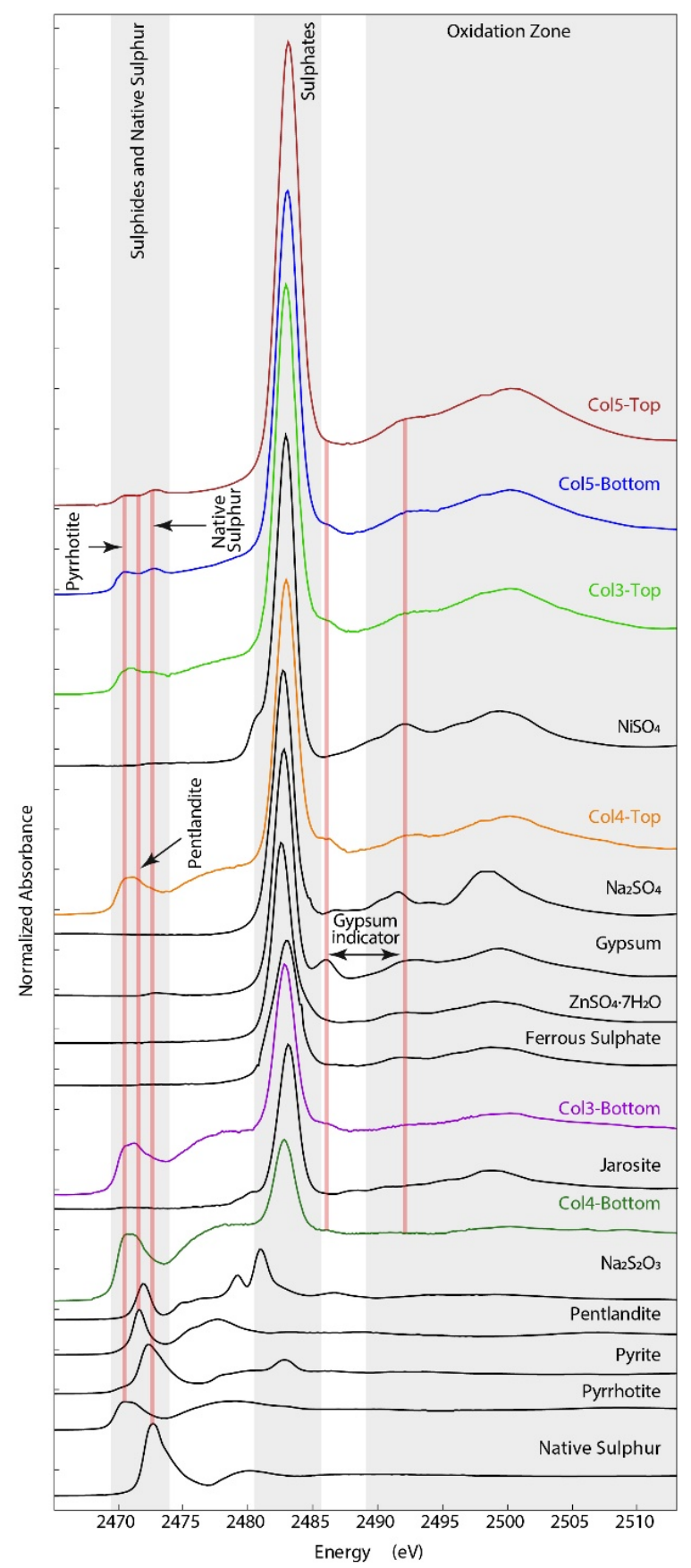

Figure 4. Normalized S K-edge XANES spectra of the samples from the top and bottom of the DST1, DST2, and RT columns and reference minerals including $\mathrm{NiSO}_{4}, \mathrm{Na}_{2} \mathrm{SO}_{4}$, gypsum, $\mathrm{ZnSO}_{4} \cdot 7 \mathrm{H}_{2} \mathrm{O}$, ferrous sulphate, jarosite, sodium thiosulphate $\left(\mathrm{Na}_{2} \mathrm{~S}_{2} \mathrm{O}_{3}\right)$, pentlandite, pyrite, pyrrhotite, and native sulphur $\left(S^{0}\right)$.

The XANES spectra (Figure 4) indicate that the DST and RT were predominantly enriched with different sulphate sulphur species, with broad peaks between $2.480 \mathrm{keV}$ and $2.485 \mathrm{keV}$. The samples produced peaks that coincide with pyrrhotite and pentlandite (highlighted with red lines at about 2.470 and $2.471 \mathrm{keV}$, respectively). The presence of sulphate minerals varied between samples, higher sulphates in top (most depleted) samples compared to bottom (least depleted) samples. The most suitable sulphate candidates (with coinciding peaks) could include $\mathrm{Na}_{2} \mathrm{SO}_{4}$, gypsum, $\mathrm{NiSO}_{4}$, iron sulphate, $\mathrm{ZnSO}_{4} \cdot 7 \mathrm{H}_{2} \mathrm{O}$, and jarosite. The predominant presence of sulphate species in the DST, in large, explains the high sulphate leaching from the columns. 


\subsubsection{The Efficiency of DST vs. RT to Control Ni and Zn Leaching}

To further validate the idea that the desulphurization of the tailings is a viable option to produce clean tailings that can be utilized as MRL in ICCBEs, the results from the column leaching experiments were used to calculate the efficiency of the DST against RT in terms of leachability of the two primary contaminants of interest, Zn and Ni (Figure 5).
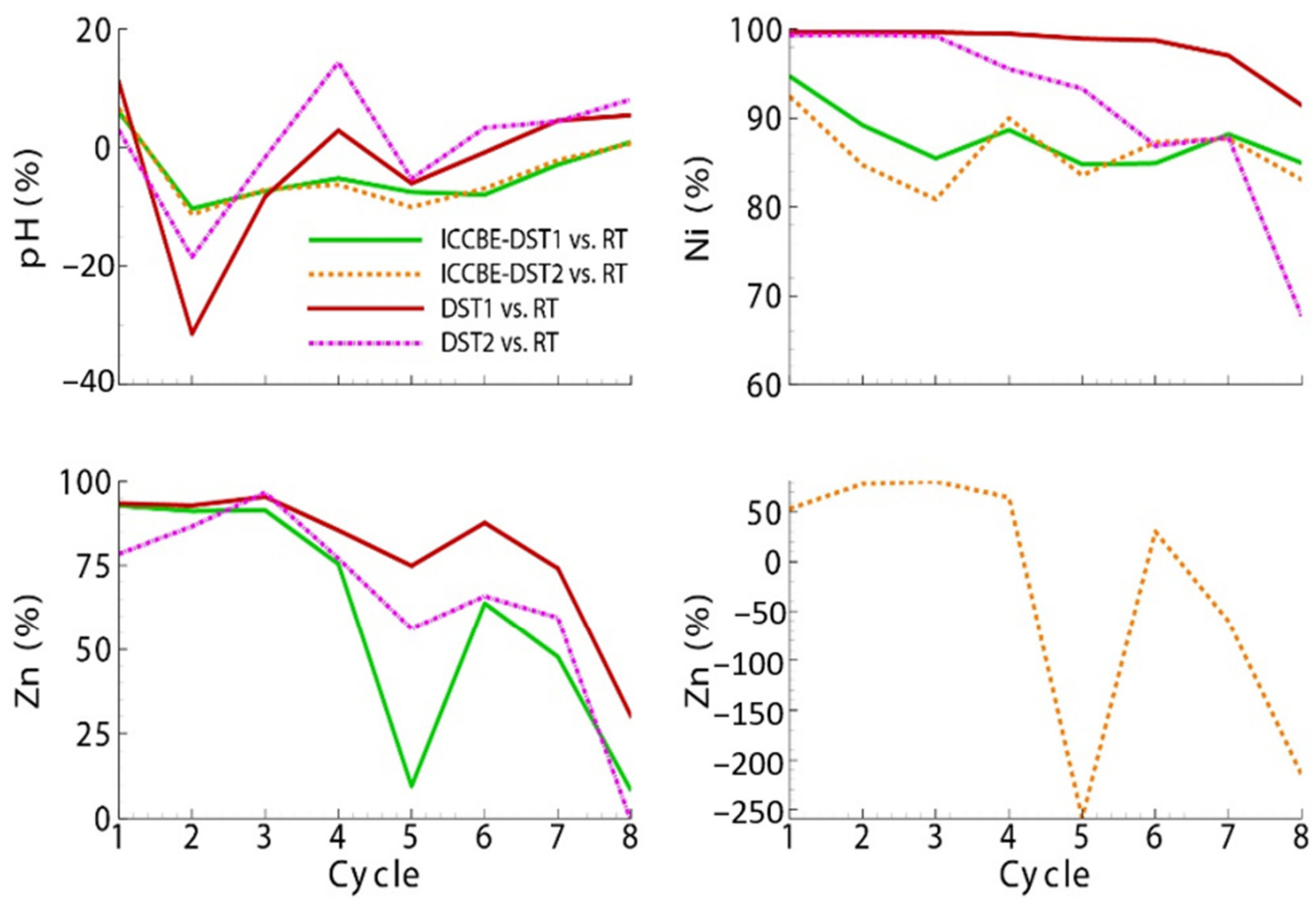

Figure 5. Efficiency of DST with and without ICCBEs vs. RT (Positive values indicate percent lower compared to RT; negative values indicate percent higher compared to RT).

DST, alone or when included in ICCBE, leached less Ni than RT (Table 5). Nickel concentrations from the DST columns (with and without ICCBEs) ranged from 0.01 to $0.22 \mathrm{mg} \mathrm{L}^{-1}$, which was considerably lower than $0.63-1.92 \mathrm{mg} \mathrm{L}^{-1}$ from RT. Moreover, the average leached $\mathrm{Ni}$ concentrations from the DST columns (Table 6) ranged from 0.12 to $0.14 \mathrm{mg} \mathrm{L}^{-1}$ (ICCBE columns) and $0.02-0.07 \mathrm{mg} \mathrm{L}^{-1}$ (DST columns) compared to $1.1 \mathrm{mg} \mathrm{L}^{-1}$ from RT. Nickel showed a descending trend from the ICCBE columns and an ascending trend from the DST columns throughout the experiment. Showing that, despite the initially higher $\mathrm{Ni}$ leaching probably due to higher sulphide reactivity and due to a contribution from the crushed WRs used as PL and CBL, columns with ICCBEs have the tendency to reduce Ni leaching over time.

On the other hand, $\mathrm{Zn}$ release from the DST columns with ICCBEs was higher than the RT at some instances, with concentrations ranging from 0.07 to $1.72 \mathrm{mg} \mathrm{L}^{-1}$ (Table 5, Figure 3). On the contrary, DST columns without ICCBEs leached lesser Zn (0.05-0.79 $\mathrm{mg} \mathrm{L}^{-1}$ ) than RT (Table 5). On average, the concentration of Zn was 0.27 and $0.90 \mathrm{mg} \mathrm{L}^{-1}$ from ICCBE-DST1 and ICCBE-DST2, respectively, 0.15 and $0.23 \mathrm{mg} \mathrm{L}^{-1}$ from the DST1 and DST2 columns, respectively, compared to $1.13 \mathrm{mg} \mathrm{L}^{-1}$ from RT (Table 6). However, by recalculating the average concentration excluding the first flush (with highest concentrations from all the columns), the average Zn leaching from ICCBE-DST2 and RT was $\sim 0.77 \mathrm{mg} \mathrm{L}^{-1}$ from both of these columns. Although there was no $\mathrm{Zn}$ associated mineral detected by XRD and SEM in any of the sampled materials, Éthier [39] determined through Electron Probe Microanalysis on RT that Zn was present as trace substitution 
in pyrrhotite grains. Therefore, it is expected that $\mathrm{Zn}$ is either hosted by other sulphide minerals (such as pyrrhotite [39] and sphalerite [40] in untraceable concentrations) or by $\mathrm{Zn}$-sulphates as indicated by XANES spectra (Figure 4). Furthermore, the solid chemical characterization (Table 4) also showed that the DSTs contained higher solid Zn than the RT (DST1 > DST2 > RT), which can be in agreement that Zn indeed is locked in other minerals (especially sulphides) that, upon desulphurization or stimulus experimental conditions (such as rigorous flushing), becomes available and thus leaches more actively. However, columns with DST2 produced more Zn pronounced leachates, probably due to higher sulphide content and their reactivity, which also lead to instability of Zn in PBL, thus resulted in higher Zn leaching from ICCBE-DST2, despite using desulphurized tailings in MRL.

Table 6. Cumulative total concentration, average leached concentrations and total depletion of $\mathrm{Ni}$ and $\mathrm{Zn}$ from the columns.

\begin{tabular}{|c|c|c|c|c|c|c|c|}
\hline \multirow{2}{*}{ Sample } & \multirow{2}{*}{$\begin{array}{c}\text { Element } \\
\text { Total Cycles }\end{array}$} & \multicolumn{3}{|c|}{$\mathrm{Ni}\left(\mathrm{mg} \mathrm{L}^{-1}\right)$} & \multicolumn{3}{|c|}{$\mathrm{Zn}\left(\mathrm{mg} \mathrm{L}^{-1}\right)$} \\
\hline & & Total & Average & Depletion (\%) & Total & Average & Depletion (\%) \\
\hline \multirow{2}{*}{ ICCBE-DST1 } & 8 Cycles & 1.00 & 0.12 & 0.004 & 2.15 & 0.27 & 0.08 \\
\hline & 7 Cycles* & 0.90 & 0.13 & - & 1.88 & 0.27 & - \\
\hline \multirow{2}{*}{ ICCBE-DST2 } & 8 Cycles & 1.15 & 0.13 & 0.004 & 7.10 & 0.89 & 0.27 \\
\hline & 7 Cycles * & 1.01 & 0.14 & - & 5.38 & 0.77 & - \\
\hline \multirow{2}{*}{ DST1 } & 8 Cycles & 0.12 & 0.01 & 0.002 & 1.19 & 0.15 & 0.27 \\
\hline & 7 Cycles* & 0.11 & 0.02 & - & 0.95 & 0.14 & - \\
\hline \multirow{2}{*}{ DST2 } & 8 Cycles & 0.55 & 0.07 & 0.006 & 2.37 & 0.30 & 0.36 \\
\hline & 7 Cycles* & 0.53 & 0.08 & - & 1.58 & 0.23 & - \\
\hline \multirow{2}{*}{$\mathrm{RT}$} & 8 Cycles & 8.77 & 1.10 & 0.05 & 9.08 & 1.13 & 0.78 \\
\hline & 7 Cycles* & 6.85 & 0.98 & - & 5.39 & 0.77 & - \\
\hline
\end{tabular}

* Excluding first rinse.

Because concentrations of $\mathrm{Zn}$ from ICCBE-DST2 were slightly above (and just below DST2) the regulatory criteria $\left(0.5 \mathrm{mg} \mathrm{L}^{-1}\right.$ ) at some instances, $\mathrm{Zn}$ (as well as Ni) depletion factor was calculated using the normalized total leached concentrations based on the sample's weight (including PL and CBL in case of ICCBE columns) and the recovered leachate volume. The depletion factors for both elements from all the columns are given in Table 6, which shows that regardless of the tailings' type and the column configuration, the depletion of $\mathrm{Ni}$ and $\mathrm{Zn}$ was very low, probably due to the low reactivity of sulphide minerals due to low-temperature experimental conditions [3] and well-maintained physicochemical conditions throughout the experiment. Therefore, it is important to pay special attention to the materials' selection for the construction of ICCBEs because the duration of $\mathrm{Zn}$ and $\mathrm{Ni}$ leaching could be potentially long.

\section{Conclusions}

This study was performed to characterize the environmental behaviour of the ICCBEs constructed in columns with desulphurized tailings and non-acid generating WRs. The columns were tested under controlled laboratory conditions inspired by the mine site's temperature and precipitation conditions.

The $\mathrm{pH}$ of the leachates from all the columns remained circumneutral to slightly alkaline. Although ICCBE-DST2 leached higher (or equal) Zn compared to RT at some instances, all other DST columns produced less Zn compared to RT on average. The DST2 columns with and without ICCBEs were less efficient in reducing $\mathrm{Zn}$ and Ni leaching because DST2 contained higher residual sulphide minerals and the PL and CBL were constructed from the WRs that contained roughly an equivalent solid content of $\mathrm{Zn}$ as of DST and $170 \mathrm{mg} \mathrm{kg}^{-1}$ of Ni. The experimental results favour the use of DST to construct ICCBEs to prevent environmental contamination overall. Furthermore, the combination of desulphurized tailings (as MRL) with non-acid generating WRs (as PL and CBL) to create 
ICCBE further improves the system's acid buffering capacity and also reduces the AMD generation risks by providing additional non-acid generating gangue minerals, resulting in better leachate quality. However, the minerals in WRs (upon dissolution) can also increase metal leaching. Therefore, the materials for the construction of ICCBEs must be selected carefully to reduce environmental contamination risks.

Finally, it is worth mentioning that to understand better the long-term behaviour of the materials and the proposed utilisation of DSTs and non-acid generating WRs for the construction of ICCBEs, the study of short- and long-term evolution of geochemical behaviour is underway through reactive transport modelling. Furthermore, the effects of absorption and adsorption would also be studied to determine their effect on $\mathrm{Ni}$ and $\mathrm{Zn}$ leaching, for instance.

Author Contributions: Conceptualization, B.B. and M.B.; methodology, B.B. and M.B.; formal analysis, F.L.; investigation, F.L.; data curation, F.L. and A.Q.; validation, B.B. and A.Q.; interpretation, A.Q.; writing—original draft preparation, A.Q.; writing—review and editing, B.B., M.B. and V.B.M.; data visualization and digital art, A.Q.; supervision, B.B. and M.B.; project administration, B.B.; funding acquisition, B.B. All authors have read and agreed to the published version of the manuscript.

Funding: This study was funded by the NSERC Industrial Chair on Mine Site Reclamation (Grant number: IRCPJ 252714-18) and by the Research Institute on Mines and the Environment (RIME UQAT-Polytechnique; www.irme.ca). The first author's research was also partially funded by the NSERC Strategic Partnership Grants for Networks "NSERC toward Environmentally Responsible Resource Extraction" (NSERC-TERRE-NET; Grant number: NETGP 479708-15).

Institutional Review Board Statement: Not applicable.

Informed Consent Statement: Not applicable.

Data Availability Statement: All data generated or analyzed during this study are included in this manuscript.

Acknowledgments: The authors wish to thank the staff at Raglan Mine's environment department (Mélanie Côté, Guy Dufour, and Louis Marcoux) for their support, as well as the personnel at URSTM (in particular Mathieu Villeneuve, Hassan Bouzahzah, Alain Perreault, Patrick Bernèche, Joel Beauregard, Tony Grondin, and Yvan Poirier) for their assistance during the laboratory work. The authors also wish to extend thanks to Marie-Pier Ethier (UQAT) and Emily Marie Saurette (UWaterloo) for helping with the synchrotron (XANES) analyses at Canadian Light Source Inc., Saskatchewan.

Conflicts of Interest: The authors declare that they have no conflict of interest. The funders had no role in the design of the study; in the collection, analyses, or interpretation of data; in the writing of the manuscript, or in the decision to publish the results.

\section{References}

1. Lottermoser, B. Mine Wastes Characterization, Treatment and Environmental Impacts; Springer: Berlin, Germany, 2014; ISBN 9783642446092.

2. Blowes, D.W.; Ptacek, C.J.; Jambor, J.L.; Weisener, C.G.; Paktunc, D.; Gould, W.D.; Johnson, D.B. The Geochemistry of Acid Mine Drainage. In Treatise on Geochemistry: Second Edition; Elsevier Inc.: Amsterdam, The Netherlands, 2013; Volume 11, pp. 131-190. ISBN 9780080983004.

3. Bussière, B.; Guittonny, M. Hard Rock Mine Reclamation: From Prediction to Management of Acid Mine Drainage; CRC Press: Boca Raton, FL, USA, 2020.

4. Benzaazoua, M.; Bussière, B.; Kongolo, M.; McLaughlin, J.; Marion, P. Environmental desulphurization of four Canadian mine tailings using froth flotation. Int. J. Miner. Process. 2000, 60, 57-74. [CrossRef]

5. Aubertin, M.; Bussière, B.; Pabst, T.; James, M.; Mbonimpa, M. Review of the Reclamation Techniques for Acid-Generating Mine Wastes upon Closure of Disposal Sites. In Proceedings of the Geo-Chicago 2016, Chicago, IL; American Society of Civil Engineers: Reston, VA, USA, 2016; pp. 343-358.

6. Boulanger-Martel, V.; Bussière, B.; Côté, J. Thermal behaviour and performance of two field experimental insulation covers to control sulfide oxidation at Meadowbank mine, Nunavut. Can. Geotech. J. 2020, 1-14. [CrossRef]

7. Bussière, B.; Hayley, D. Effects of Climate Change on Mine Waste Disposal in the Arctic. Geo-Strat. Geo Inst. ASCE 2010, 14, 44-46.

8. Boulanger-Martel, V.; Bussière, B.; Côté, J.; Mbonimpa, M. Influence of freeze-thaw cycles on the performance of covers with capillary barrier effects made of crushed rock-bentonite mixtures to control oxygen migration. Can. Geotech. J. 2016, 53, 753-764. [CrossRef] 
9. Boulanger-Martel, V.; Bussière, B.; Côté, J. Insulation Covers. In Hard Rock Mine Reclamation: From Prediction to Management of Acid Mine; Bussière, B., Guittonny, M., Eds.; CRC Press: Boca Raton, FL, USA, 2020.

10. Lessard, F.; Bussière, B.; Côté, J.; Benzaazoua, M.; Boulanger-Martel, V.; Marcoux, L. Integrated environmental management of pyrrhotite tailings at Raglan Mine: Part 2 desulphurized tailings as cover material. J. Clean. Prod. 2018, 186, 883-893. [CrossRef]

11. Meldrum, J.L.; Jamieson, H.E.; Dyke, L.D. Oxidation of mine tailings from Rankin Inlet, Nunavut, at subzero temperatures. Can. Geotech. J. 2001, 38, 957-966. [CrossRef]

12. Kyhn, C.; Elberling, B. Frozen cover actions limiting AMD from mine waste deposited on land in Arctic Canada. Cold Reg. Sci. Technol. 2001, 32, 133-142. [CrossRef]

13. Boulanger-Martel, V.; Bussière, B.; Cote, J.; Gagnon, P. Design, construction, and preliminary performance of an insulation cover with capillary barrier effects at Meadowbank mine, Nunavut. In Proceedings of the 70th Canadian Geotechnical Conference, Ottawa, ON, Canada, 1-4 October 2017; p. 354.

14. Boulanger-Martel, V.; Bussière, B.; Côté, J. Insulation covers with capillary barrier effects to control sulfide oxidation in the Arctic. Can. Geotech. J. 2020. [CrossRef]

15. Bussière, B. Colloquium 2004: Hydrogeotechnical properties of hard rock tailings from metal mines and emerging geoenvironmental disposal approaches. Can. Geotech. J. 2007, 44, 1019-1052. [CrossRef]

16. Bussière, B.; Aubertin, M.; Mbonimpa, M.; Molson, J.W.; Chapuis, R.P. Field experimental cells to evaluate the hydrogeological behaviour of oxygen barriers made of silty materials. Can. Geotech. J. 2007, 44, 245-265. [CrossRef]

17. Bussière, B.; Benzaazoua, M.; Aubertin, M.; Mbonimpa, M. A laboratory study of covers made of low-sulphide tailings to prevent acid mine drainage. Environ. Geol. 2004, 45, 609-622. [CrossRef]

18. Benzaazoua, M.; Bouzahzah, H.; Taha, Y.; Kormos, L.; Kabombo, D.; Lessard, F.; Bussière, B.; Demers, I.; Kongolo, M. Integrated environmental management of pyrrhotite tailings at Raglan Mine: Part 1 challenges of desulphurization process and reactivity prediction. J. Clean. Prod. 2017, 162, 86-95. [CrossRef]

19. Bussière, B.; Lelièvre, J.; Ouellet, J.; Bois, D. Utilisation de résidus miniers désulfurés comme recouvrement pour prévenir le DMA: Analyse technico-économique sur deux cas réels. In Proceedings of the Sudbury '95 Conference on Mining and the Environment, Sudbury, ON, Canada, 28 May-1 June 1995; pp. 59-68.

20. Aubertin, M.; Aachib, M.; Monzon, M.; Joanes, A.M.; Bussière, B.; Chapuis, R.P. Étude de Laboratoire sur L'efficacité des Barrières de Recouvrement Construites à Partir de Résidus Miniers; Ecole Polytechnique de Montréal: Montreal, QC, Canada, 1997.

21. Aachib, M.; Mbonimpa, M.; Aubertin, M. Measurement and Prediction of the Oxygen Diffusion Coefficient in Unsaturated Media, with Applications to Soil Covers. Water Air Soil Pollut. 2004, 156, 163-193. [CrossRef]

22. Bussière, B. Etude du Comportement Hydrique de Couvertures avec Effets de Barrieres Capillaires Inclinees a L'aide de Modelisations Physiques et Numeriques; Ecole Polytechnique de Montreal: Montreal, QC, Canada, 1999.

23. Dagenais, A.-M. Techniques de Contrôle du Drainage Minier Acide Basées sur les Effets Capillaires; Ecole Polytechnique de Montreal: Montreal, QC, Canada, 2005.

24. Nastev, M.; Aubertin, M. Hydrogeological modelling for the reclamation work at the Lorraine mine site Québec. In Proceedings of the 1st Joint IAH-CNC-CGS Groundwater Specialty Conference, Montreal, QC, Canada, 15-18 October 2000; pp. 311-318.

25. Gosselin, M. Étude de l'influence des Caractéristiques Hydrogéochimiques des Résidus Miniers Réactifs sur la Diffusion et la Consommation de L'oxygène, Polytechnique de Montréal; Département des Génies Civil, Géologique et des Mines, Polytechnique Montréal: Montreal, QC, Canada, 2007.

26. ASTM Standard Test Method for Particle-Size Analysis of Soils (D422-63); ASTM International: West Conshohocken, PA, USA, 2007.

27. Coulombe, V. Performance de Recouvrements Isolants Partiels Pour Contrôler L'oxydation de Résidus Miniers Sulfureux; Université du Québec en Abitibi-Témiscamingue: Rouyn-Noranda, QC, Canada, 2012.

28. Bouzahzah, H. Modification et Amélioration des Tests Statiques et Cinétiques pour une Prédiction Fiable du Drainage Minier acide. Ph.D. Thesis, Université du Québec en Abitibi-Témiscamingue (UQAT), Rouyn-Noranda, QC, Canada, 2013.

29. CENTRE D'EXPERTISE EN ANALYSE ENVIRONNEMENTALE DU QUÉBEC. Determination du Carbone et du Soufre: Methode par Combustion et Dosage par Spectrophotometrie Infrarouge; MA. 310 e CS 1.0, Rev. 3; Ministere du Developpement durable, de l'Environnement, de la Faune et des Parcs du Quebec: Quebec City, QC, Canada, 2013.

30. Moncur, M.C.; Ptacek, C.J.; Lindsay, M.B.J.; Blowes, D.W.; Jambor, J.L. Long-term mineralogical and geochemical evolution of sulfide mine tailings under a shallow water cover. Appl. Geochem. 2015, 57, 178. [CrossRef]

31. Ravel, B.; Newville, M. ATHENA, ARTEMIS, HEPHAESTUS: Data analysis for X-ray absorption spectroscopy using IFEFFIT. J Synchrotron Radiat. 2005, 12, 537-541. [CrossRef] [PubMed]

32. Sobek, A.; Schuller, W.; Freeman, J.; Smith, R. Field and Laboratory Methods Applicable to Overburdens and Minesoils; U.S. Environmental Protection Agency: Washington, DC, USA, 1978.

33. Lawrence, R.W.; Scheske, M. A method to calculate the neutralization potential of mining wastes. Environ. Geol. 1997, 32, 100-106. [CrossRef]

34. Boulanger-Martel, V.; Bussière, B.; Côté, J.; Mbonimpa, M. Laboratory column experiment to evaluate oxygen diffusion through covers with capillary barrier effects subjected to freeze-thaw cycles. In Proceedings of the 16th International Conference on Cold Regions Engineering, Salt Lake City, UT, USA, 19-22 July 2015; Volume 19.

35. McCarthy, D.F. Essentials of Soil Mechanics and Foundations: Basic Geotechnics; Pearson/Prentice Hall: London, UK, 2007; ISBN 9780131145603. 
36. Aubertin, M.; Chapuis, R.P.; Aachib, M.; Bussière, B.; Ricard, J.F.; Tremblay, L. Évaluation en Laboratoire de Barrières Sèches Construites à Partir de Résidus Miniers; Ecole Polytechnique de Montréal: Montreal, QC, Canada, 1995.

37. Pedroza, F.R.C.; Aguilar, M.D.J.S.; Treviño, T.P.; Luévanos, A.M.; Castillo, M.S. Treatment of sulfide minerals by oxidative leaching with ozone. Miner. Process. Extr. Metall. Rev. 2012, 33, 269-279. [CrossRef]

38. Larochelle, C.G.; Bussière, B.; Pabst, T. Acid-Generating Waste Rocks as Capillary Break Layers in Covers with Capillary Barrier Effects for Mine Site Reclamation. Water Air Soil Pollut. 2019, 230, 57. [CrossRef]

39. Éthier, M.-P. Évaluation du Comportement Géochimique en Conditions Normale et Froides de Différents Stériles Présents sur le Site de La mine Raglan; Université du Québec en Abitibi-Témiscamingue: Rouyn-Noranda, QC, Canada, 2011.

40. Vaughan, D.J. Minerals I Sulphides. Ref. Modul. Earth Syst. Environ. Sci. 2013. [CrossRef] 